\title{
GMR
}

\section{Association among agro-industrial traits and simultaneous selection in sweet sorghum}

\author{
P.S.S. Leite ${ }^{1}$, T.G. Fagundes ${ }^{1}$, J.A.R. Nunes ${ }^{1}$, R.A.C. Parrella ${ }^{2}$, \\ N.N.L. Durães ${ }^{3}$ and A.T. Bruzi ${ }^{4}$ \\ ${ }^{1}$ Departamento de Biologia, Universidade Federal de Lavras, Lavras, MG, Brasil \\ ${ }^{2}$ Embrapa Milho e Sorgo, Sete Lagoas, MG, Brasil \\ ${ }^{3}$ Departamento de Melhoramento de Plantas, \\ Universidade Estadual do Norte Fluminense Darcy Ribeiro, \\ Campos dos Goytacazes, RJ, Brasil \\ ${ }^{4}$ Departamento de Agricultura, Universidade Federal de Lavras, Lavras, \\ MG, Brasil \\ Corresponding author: P.S.S. Leite \\ E-mail: pakizza@hotmail.com
}

Genet. Mol. Res. 16 (1): gmr16019318

Received September 20, 2016

Accepted November 18, 2016

Published January 23, 2017

DOI http://dx.doi.org/10.4238/gmr16019318

Copyright (C) 2017 The Authors. This is an open-access article distributed under the terms of the Creative Commons Attribution ShareAlike (CC BY-SA) 4.0 License.

\begin{abstract}
Sweet sorghum has emerged as an alternative crop for ethanol yield. The breeding of this crop is performed to obtain cultivars with high ethanol yield, which necessarily requires associating favorable phenotypes for multiple traits. Therefore, the aims of this study were to investigate the association between agro-industrial traits related to ethanol yield and identify the promising genotypes considering multiple traits in sweet sorghum. For this purpose, we evaluated 45 genotypes using a 9 x 5 alpha-lattice experimental design with three replications. The traits measured were flowering time, plant height, tons of stalk per hectare, total soluble solids, tons of brix per hectare, juice extraction, total recoverable sugars, and ethanol yield. Analyses were performed
\end{abstract}

Genetics and Molecular Research 16 (1): gmr16019318 
after the recovery of inter-block information. The interrelation of the traits was described by genotype-by-trait biplot. For simultaneous selection, the Modified Mulamba and Mock index was used. For almost all of the agro-industrial traits, except for juice extraction, selective accuracy was above $70 \%$. There were significant differences among genotypes for all the traits. The genotype-by-trait biplot evidenced a positive association between most of the traits related to ethanol yield, except for juice extraction, indicating the possibility of indirect selection to obtain more productive genotypes. Some genotypes proved to be promising based on the selection index, as they accumulated phenotypes favorable for the traits of interest.

Key words: Sorghum bicolor; Selection index; Genotype-by-trait biplot; Ethanol yield

\section{INTRODUCTION}

The main feedstock for the ethanol production chain is sugar cane. However, there is a need to seek complementary bioenergy crops, especially during the off-season of sugarcane. Sweet sorghum is a promising alternative for this purpose [Sorghum bicolor (L.) Moench] (Kim and Day, 2011). This crop has a short cycle (Rohowsky et al., 2013); easy management and mechanization, which are accessible to most farmers; and contains high concentrations of sugars in the stalk equivalent to sugarcane, besides having wide adaptability and lower demand for inputs (Azevedo et al., 2003; Regassa and Wortmann, 2014).

Breeding programs of sweet sorghum are mainly focused on obtaining superior cultivars for ethanol yield that are resistant to lodging, with longer period of industrial use, have resistance/tolerance to biotic and abiotic stresses, and possess technological characteristics demanded by the market, besides being stable to environmental variations and responsive to environmental improvement.

Selection based on sweet sorghum ideotype requires prior knowledge about the correlation of traits, as the magnitude and direction of associations can directly affect the selection strategies to be adopted. The genotype-by-trait biplot proposed by Yan and Rajcan (2002) allows the visualization of correlations between multiple characteristics. Furthermore, it allows the identification variables that are less important and the ones that are most appropriate for indirect selection, based on a target characteristic.

For simultaneous selection, an alternative method is the use of selection index. Studies involving selection indexes have been conducted with various crops, such as corn (Santos et al., 2007), bean (Bertini et al., 2010), passion fruit (Gonçalves et al., 2007), soybean (Costa et al., 2004), eucalyptus (Paula et al., 2002), and sugarcane (Pedrozo et al., 2009). Despite the efficiency of selection indexes, this strategy has been scarcely explored in sweet sorghum.

The literature contains several selection indexes (Smith, 1936; Hazel, 1943; Williams, 1962; Mulamba and Mock, 1978). Among these, because of its practicality and ease of interpretation, we highlight the Mulamba and Mock index, which is based on classifications or ranks of genotypes on the traits under selection in the direction desired by the breeder. However, the original Mulamba and Mock index has the disadvantage of not involving a statistical test to discriminate genotypes. The modified Mulamba and Mock index $\left(\mathrm{I}_{\mathrm{MM}}\right)$, as

Genetics and Molecular Research 16 (1): gmr16019318 
described by Ramalho et al. (2012), adds this inferential aspect.

Therefore, the aim of the present study was to investigate the association among agro-industrial traits related to ethanol yield using genotype-by-trait biplot and identify the promising genotypes, considering multiple agro-industrial traits in sweet sorghum.

\section{MATERIAL AND METHODS}

\section{Description and location of the experiment}

The experiment was conducted at the Center of Scientific and Technological Development in Agriculture and Livestock, Federal University of Lavras, Lavras city, state of Minas Gerais, in the 2012/2013 growing year. The soil type of the area is Typical Distroferric Red Latosol. The municipality of Lavras is located at $918 \mathrm{~m}$ in altitude, $21^{\circ} 14 ' \mathrm{~S}$ and $45^{\circ} 00^{\prime} \mathrm{W}$, has average annual temperature $19.4^{\circ} \mathrm{C}$ and average annual rainfall of $1529.7 \mathrm{~mm}$.

We evaluated 45 genotypes in the Breeding Program, belonging to Brazilian Corporation for Agricultural Research (Embrapa) Maize and Sorghum, including 10 fertility restorer lines (BR500, BR501, BR504, BR505, CMSXS633, CMSXS634, CMSXS642, CMSXS643, CMSXS644, and CMSXS647), three male sterile lines (BR007, BR008, and BR222), 30 hybrids resulting from the partial diallel cross between male sterile lines and fertility restorer lines, and two commercial hybrids (XBSW80007 and XBSW80147).

The experimental design consisted of a $9 \times 5$ alpha-lattice with three replications. The experimental plots consisted of two $5.0 \mathrm{~m}$ long rows. The spacing between rows was $0.7 \mathrm{~m}$ and the population density was 140.000 plants per hectare. Three agronomic and five technological traits were analyzed. The agronomic traits that were analyzed were flowering time (FLOW), i.e., number of days from sowing to flowering of $50 \%$ plants of the plot, plant height $(\mathrm{PH})$, i.e., average height $(\mathrm{m})$ of eight plants taken randomly from the plot and measured from the ground to the apex of the panicle, and tons of stalk per hectare (TSH), i.e., plants of the plot without leaves and panicles were weighed on a hanging digital scale and the data was expressed in $\mathrm{t} / \mathrm{ha}$.

The technological traits that were analyzed were total soluble solids (TSS), which is determined from the juice using an automatic digital refractometer $\left({ }^{\circ}\right.$ Brix); juice extraction (EXT), i.e., eight whole plants were randomly taken per plot, without panicles and without leaves and juice was extracted from a subsample of $500 \pm 0.5 \mathrm{~g}$ in a hydraulic press, with a minimum and constant pressure of $250 \mathrm{kgf} / \mathrm{cm}^{2}$ on the sample for 1 minute; tons of brix per hectare $(\mathrm{TBH})$ as the product of TBH $=$ GMY $\times$ EXT $\times$ TSS, which GMY is the green mass yield per hectare; total recoverable sugars (TRS) in kg sugar per ton of stalk, which were determined by the equation (Consecana, 2006): TRS $=(10 \times \mathrm{SC} \times 1.05263 \times 0.905)+(10 \mathrm{x}$ TReS x 0.905), in which SC is the sucrose content in \% juice (percentage of sucrose by weight of juice), 1.05263 is the stoichiometric coefficient for conversion of sucrose into reducing sugar, TReS is the amount of total reducing sugars in \% juice, and 0.905 is the recovery coefficient for an industrial loss of 9.5\%; and ethanol yield in L/ha (EY) was calculated by the equation described at the Consecana guide (2006): EY = PHE x GMY, where PHE is the production of hydrous ethanol in L per ton of stalk.

Additionally, the value of $\mathrm{I}_{\mathrm{MM}+}$ at the level of plot was determined, according to Ramalho et al., (2012). Data of each plot related to the above agro-industrial traits were transformed into ranks and then were added up, obtaining the value of the index for each plot.

Genetics and Molecular Research 16 (1): gmr16019318 


\section{Statistical analysis}

Analysis of variance with recovery of inter-block information was applied to data of traits and $\mathrm{I}_{\mathrm{MM}^{+}}$according to the following statistical model:

$$
y_{i j k}=\mu+r_{i}+b_{(i) j}+g_{k}+e_{i j k}
$$

(Equation 1)

where, $y_{i j k}$ is the observation of the plot of block $j$ within repetition $i$ that received genotype $k ; \mu$ is a constant associated with all observations; $r_{i}$ is the effect of repetition $i, r_{i} \sim N\left(0, \sigma_{r}^{2}\right)$; $b_{(i j j}$ is the effect of block $j$ within repetition $i, b_{(i) j} \sim N\left(0, \sigma_{b}^{2}\right) ; g_{k}$ is the effect of genotype $k ; e_{i j k}$ is the experimental error associated with $y_{i j k} ; e_{i j k} \sim N\left(0, \sigma^{2}\right)$. The parameters $\sigma_{r}^{2}, \sigma_{b}^{2}$, and $\sigma_{e}^{2}$ refer to variances associated with random effects of repetitions, blocks within repetitions, and error, respectively.

The experimental precision was determined by estimating the selective accuracy (Resende and Duarte, 2007). Adjusted phenotypic means of genotypes were clustered using the Scott-Knott test (Scott and Knott, 1974) at 5\% probability.

The description of the interrelation of traits was made by genotype-by-trait biplot, according to Yan and Rajcan (2002). According to these authors, when the biplot explains a sufficient amount of the total variance, the correlation coefficient between any two traits is approximated by the cosine of the angle between the vectors. Subsequently, the biplot was generated from the mean values of each genotype for measured traits using the software R ( $R$ Core Team, 2016).

From the analysis of the $\mathrm{I}_{\mathrm{MM}+}$, the best genotypes were defined, which were then plotted using standardization of means for each trait (Nunes et al., 2005; Mendes et al., 2009). Statistical analyses were performed in the R software (R Core Team, 2016).

\section{RESULTS}

The alpha lattice experimental design showed low efficiency $(<105 \%)$ for all the traits. Therefore, analyses were made considering a randomized complete block design.

Almost all the agro-industrial traits presented accuracy above 70\%, except EXT. The experimental precision was estimated high according to Resende and Duarte (2007; Tables 1 and 2).

Table 1. Summary of the analysis of variance of agronomic traits: flowering (FLOW, days), plant height (PH, $\mathrm{m}$ ) and tons of stalk per hectare (TSH) on the evaluation of sweet sorghum genotypes in Lavras, State of Minas Gerais, in the 2012/2013 growing season.

\begin{tabular}{l|c|c|c|c}
\hline Source of variation & \multirow{2}{*}{ d.f. } & \multicolumn{3}{|c}{ Mean square } \\
\cline { 3 - 5 } & & FLOW & PH & TSH \\
\hline Genotype & 44 & $55.79^{*}$ & $0.52^{*}$ & $355.14^{*}$ \\
\hline Error & 88 & 10.98 & 0.059 & 44.4 \\
\hline General mean & - & 77.24 & 2.96 & 41.19 \\
\hline Accuracy & - & 89.48 & 94.16 & 93.24 \\
\hline
\end{tabular}

*Significant, by the $F$-test, at $5 \%$ probability.

Genetics and Molecular Research 16 (1): gmr16019318 
Table 2. Summary of the analysis of variance of technological traits: total soluble solids (TSS, ${ }^{\circ}$ Brix), tons of brix per hectare (TBH), juice extraction (EXT, \%), total recoverable sugars (TRS, $\mathrm{kg} /$ ton stalk); ethanol yield (EY, L/ha); and modified Mulamba and Mock index $\left(\mathrm{I}_{\mathrm{MM}^{+}}\right)$, on the evaluation of sweet sorghum genotypes in Lavras, state of Minas Gerais, in the 2012/2013 growing season.

\begin{tabular}{l|c|c|c|c|c|c|c}
\hline Source of variation & d.f. & \multicolumn{6}{|c}{ Mean square } \\
\cline { 3 - 8 } & & TSS & TBH & EXT & TRS & EY & IMM+ \\
\hline Genotype & 44 & $12.32^{*}$ & $5.70^{*}$ & $34.90^{*}$ & $678.27^{*}$ & $2,602,163.2^{*}$ & $12,652.20^{*}$ \\
\hline Error & 88 & 2.73 & 0.75 & 18.96 & 162.64 & $392,861.2$ & $1,625.40$ \\
\hline General mean & - & 12.90 & 3.62 & 69.11 & 71.01 & $2,222.797$ & 183.36 \\
\hline Accuracy & - & 88.51 & 93.01 & 68.20 & 87.41 & 92.06 & 93.21 \\
\hline
\end{tabular}

*Significant, by $F$-test, at $5 \%$ probability.

There were significant differences $(\mathrm{P}<0.05)$ among sweet sorghum genotypes for all the agro-industrial traits (Tables 1 and 2). This significance can be considered as evidence of genetic variability, as has also been reported in other studies (Pfeiffer et al., 2010; Tomar et al., 2012; Souza et al., 2013).

According to the group of means (Figure 1) for FLOW, there was a variation of 7289 days. Similar values were also found by Rao et al. (2013). The lines BR501, CMSXS642, CMSXS643, and hybrid BSW80147 were highlighted for being late. This result is similar to that reported by de Figueiredo et al. (2015).
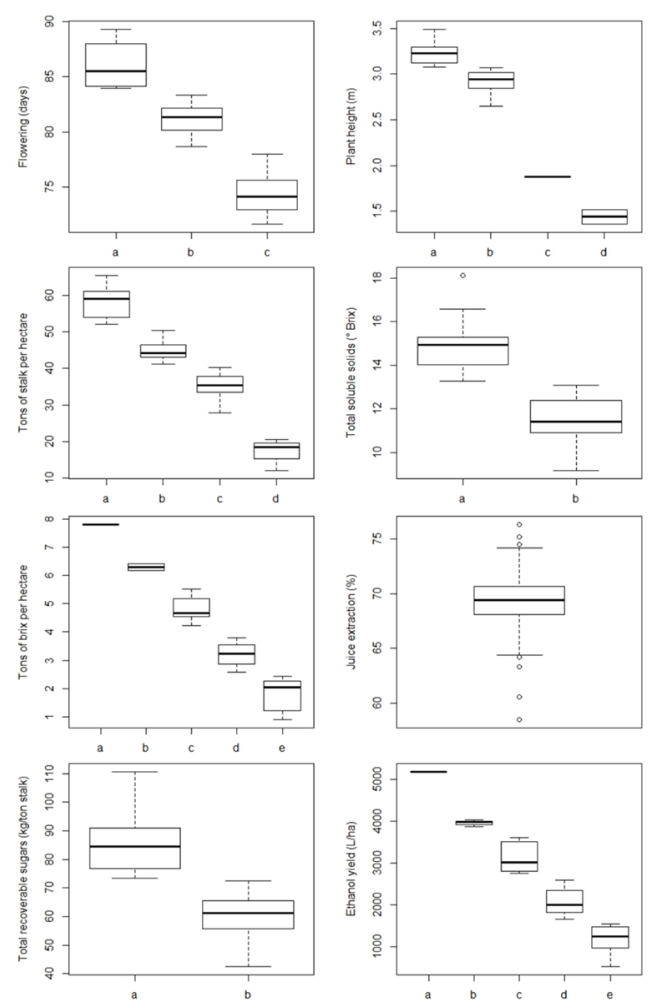

Figure 1. Boxplots of mean values of sweet sorghum genotypes according to the clustering by the Scott-Knott test at $5 \%$ probability. Vertical bar corresponds to the range of variation of each group and the central horizontal bar is the median within each group.

Genetics and Molecular Research 16 (1): gmr16019318 
PH ranged from 1.36 to $3.49 \mathrm{~m}$ (Figure 1). The male sterile lines (BR007 and BR008) were smaller, whereas the restorer lines and hybrids were larger, which facilitates mechanical harvesting. The height in sorghum is controlled by four genes that have independent and additive influence ( $D W 1, D W 2, D W 3$, and $D W 4)$, and the tall plant phenotype is partially dominant over the short plant phenotype (Quinby, 1974).

For TSH, genotypes with production ranging from 12.07 to $65.5 \mathrm{t} / \mathrm{ha}$ were divided into four groups. Similar results were reported by Tomar et al. (2012). Genotypes BR505, CMSXS634, CMSXS643, CMSXS647, BR222 x BR501, XBSW80007, and XBSW80147 had the highest mean values, whereas the male sterile lines (BR007, BR008, and BR222) had the lowest production.

In sweet sorghum breeding programs, besides agronomic traits, the variables related to the juice quality are of great interest. TSS is an important characteristic for the crop. We found that this trait ranged from 9.17 to $18.13^{\circ}$ Brix. Moreover, according to the amount of sugars, as observed from TRS, it was possible to separate the genotypes into two groups. The mean values ranged from 42.45 to $110.71 \mathrm{~kg}$ sugar per ton of stalk.

Figure 1 shows, as verified from TBH, the CMSXS643R line was superior to the other genotypes tested, with a mean value $7.81 \mathrm{t} / \mathrm{ha}$. Considering the trait EY, the same line (CMSX643R) was observed superior with a mean value of $5194.32 \mathrm{~L} / \mathrm{ha}$. For the variable EXT, there were no distinct clusters by the Scott-Knott test, although, in absolute terms, genotypes with 58.46 to $76.36 \%$ were observed.

While selecting for multiple traits, one important statistical parameter to be considered is the correlation. In this study, in order to describe the interrelationship of traits, we used the genotype-by-trait biplot. The first two principal components explained $80.5 \%$ of the total variance. This relatively high percentage of variation reflects the precision of the interrelationships between the variables measured. Figure 2 shows that the traits FLOW, PH, TSH, TSS, TBH, TRS, and EY showed medium to high positive correlations. The variable EXT showed low correlation compared to all the other traits, which is associated with low variation observed among the genotypes for this trait. The positive and high correlations found between the traits FLOW, PH, TSH, TSS, TBH, and TRS with EY indicates the possibility of indirect selection.

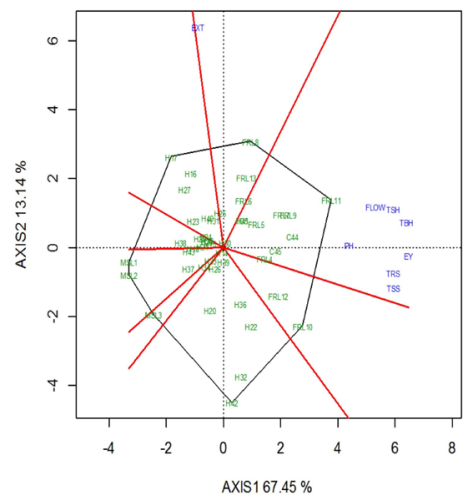

Figure 2. Biplot graphical representation of the interrelationship of sweet sorghum genotypes considering multiple agro-industrial traits. Genotypes were renamed: male sterile lines (MSL1, MSL2 and MSL3), fertility restorer lines (from FRL4 to FRL13), hybrids (from H14 to H43) and commercial hybrids (C44 and C45). FLOW = flowering (days); $\mathrm{PH}=$ plant height $(\mathrm{m}) ; \mathrm{TSH}=$ tons of stalk per hectare; $\mathrm{TSS}=$ total soluble solids ${ }^{\circ} \mathrm{Brix}$ ); $\mathrm{TBH}=$ tons of Brix per hectare; EXT = juice extraction (\%); TRS = total recoverable sugars (kg/ton stalk); EY = ethanol yield (L/ha).

Genetics and Molecular Research 16 (1): gmr16019318 
Analysis of variance for the values of $\mathrm{I}_{\mathrm{MM}^{+}}$at the level of plot ( $\left.\mathrm{I}_{\mathrm{MM}_{+}}\right)$was significant for the genotypes tested (Table 2). From the Scott-Knott test, it was possible to classify the genotypes in five different groups according to the modified $\mathrm{I}_{\mathrm{MM}+}$ (Table 3), with greater emphasis on the lines BR500, BR505, CMSXS633, CMSXS634, CMSXS642, CMSXS643, CMSXS644, and hybrid XBSW80007. Figure 3 shows that these genotypes showed high average performance for all the traits, indicating the efficiency of the index in choice of superior genotypes for multiple traits simultaneously.

Table 3. Clustering of sweet sorghum genotypes according to the Scott-Knott test at 5\% probability relative to modified Mulamba and Mock index $\left(\mathrm{I}_{\mathrm{MM}+}\right)$.

\begin{tabular}{|c|c|}
\hline Group & Genotypes \\
\hline A & BR500, BR505, CMSXS633, CMSXS634, CMSXS642, CMSXS643, CMSXS644, XBSW80007 \\
\hline B & BR501, BR504, CMSXS647, BR007 x CMSXS644, BR008 x CMSXS644, BR222 x BR501, BR222 x BR504, R222 x CMSXS643, XBSW80147 \\
\hline $\mathrm{C}$ & $\begin{array}{l}\text { BR007 x BR500, BR007 x BR501, BR007 x BR504, BR007 x CMSXS634, BR007 x CMSXS642, BR007 x MSXS643, BR007 x CMSXS647, } \\
\text { BR008 x BR500, BR008 x BR501, BR008 x BR504, BR008 x CMSXS633, } \\
\text { BR008 x CMSXS634, BR008 x CMSXS642, BR008 x CMSXS643, BR008 x CMSXS647, BR222 x BR500, BR222 x CMSXS634, BR222 x } \\
\text { CMSXS642, BR222 x CMSXS644 }\end{array}$ \\
\hline $\mathrm{D}$ & BR007 x BR505, BR007 x CMSXS633, BR008 x BR505, BR222 x BR505, BR222 x CMSXS633, R222 x CMSXS647R \\
\hline E & BR007, BR008, BR222 \\
\hline
\end{tabular}
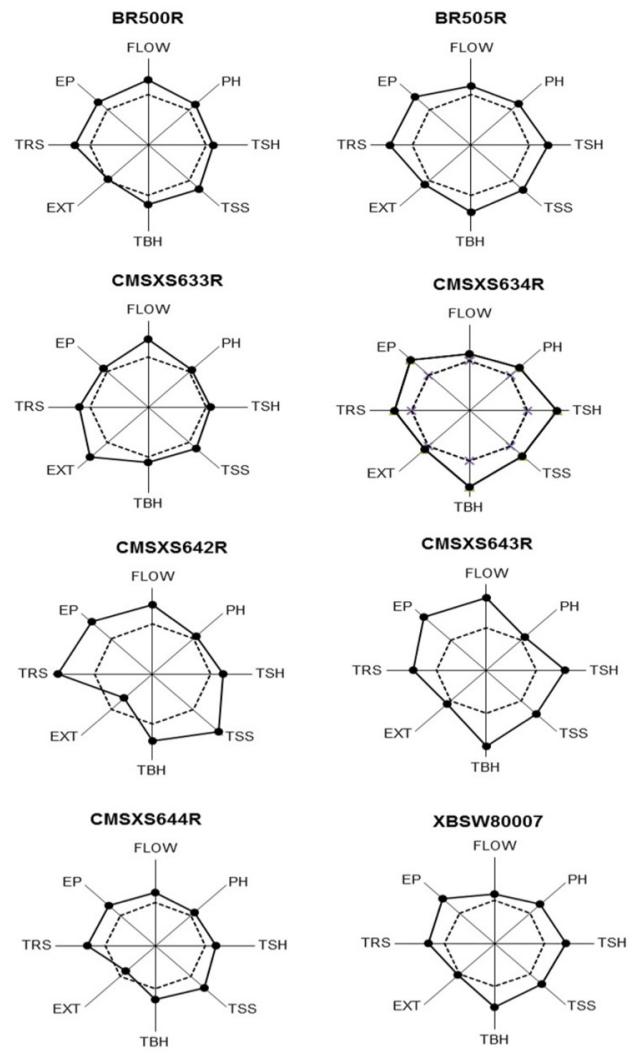

Figure 3. Graphical representation of the standardized values of the traits: FLOW = flowering (days); PH = plant height $(\mathrm{m}) ; \mathrm{TSH}=$ tons of stalk per hectare; TSS $=$ total soluble solids $\left({ }^{\circ} \mathrm{Brix}\right) ; \mathrm{TBH}=$ tons of brix per hectare; $\mathrm{EXT}=$ juice extraction (\%); TRS = total recoverable sugars $(\mathrm{kg} /$ ton stalk); EY = ethanol yield (L/ha) of genotypes showing better performances. Dashed line is the standardized mean with constant of 3.5. Each axis represents a trait. 
P.S.S. Leite et al.

\section{DISCUSSION}

Accuracy reflects the reliability in the estimation of the actual genotypic values from the observed phenotypic values. The accuracy values were consistent with those found by Tomar et al. (2012) for the traits FLOW, PH, TSH, and TSS. The authors obtained a higher accuracy for juice extraction (91.5\%). These differences in accuracy values can be attributed to differences in environmental factors as well as the genetic variances.

During simultaneous selection, it is important to consider the correlations, as they affect indirect selection of traits of interest through selection of the trait that are easier to measure and have high heritability associated. In this respect, FLOW and TSS can be selected from the results obtained.

Flowering is an important variable for genetic breeding, because there is an increase in accumulation of soluble solids in the stalk after its onset (Gutjahr et al., 2013). This trait showed high genotypic determination and strong association with ethanol yield. There is a study that indicates the oligogenic nature of genetic control of the time to flowering is made by four maturity genes $M a 1, M a 2, M a 3$, and $M a 4$ and environmental conditions, photoperiod, and temperature can influence the expression of this trait (Quinby et al., 1973).

Sweet sorghum genotypes showed TSS content ranging from 9.17 to $18.13^{\circ}$ Brix, which, according to Teetor et al. (2011), indicates that the lines/hybrids can serve as raw material for ethanol production by yeasts. According Teixeira et al. (1999), this trait is strongly influenced by the environment, and the other factors can affect the final content of soluble solids.

Despite the more complex genetic architecture of the trait TSS (Audilakshmi et al., 2010), it showed high correlation with TRS. Since TRS is a very descriptive trait of the juice quality and harder to measure, indirect selection via TSS has great practical importance. It is necessary to achieve minimum levels of sugar production for economically feasible production of ethanol from sweet sorghum (Parrella, 2011). For the trait TRS, the minimum value reaches $80 \mathrm{~kg} /$ ton stalk. In this study, 13 genotypes showed absolute values above this threshold; however, other seven genotypes did not differ statistically, as determined by Scott-Knott test, demonstrating the potential of these genotypes for ethanol yield.

For sweet sorghum breeding, several traits are analyzed, but the selection of genotypes that combine high yield of juice with high sugar content, which results in high EY is desired. Evaluating the genetic potential of sweet sorghum genotypes considering multiple traits is rare in literature. The genotype-by-trait biplot has not been used to study interrelation among the traits of sweet sorghum. In sweet sorghum breeding, information is limited to identification of traits that can be used for indirect selection. In relation to this, traits accounted for are the variable tons of brix per hectare, which is a natural index, because it takes into account the traits TSH, EXT, and TSS. The genotype-by-trait biplot pointed out a high positive association between TBH and EY, indicating the possibility of adopting these traits as criteria for indirect selection to obtain more productive genotypes, in terms of alcohol productivity. The path analysis conducted by Lombardi et al. (2015) corroborated this, revealing that TBH showed significant direct effect on the ethanol yield.

Using the $\mathrm{I}_{\mathrm{MM}^{+}}$, since the transformation into posts was performed at the level of plot, we noted its efficiency in identifying superior genotypes for the traits of interest. Another advantageous fact that should be emphasized is the ability to discriminate the genotypes based on the index by comparison test or grouping of means. In this study, we found that the lines CMSXS642 and CMSXS643 demonstrated superior performance for production of stalks rich

Genetics and Molecular Research 16 (1): gmr16019318 
in soluble solids. According to Wu et al. (2010), the TSS stored in the stalk mainly consist of sucrose, glucose, and fructose. These sugars have desirable characteristics for alcoholic fermentation making their conversion into ethanol possible (Andersson and Hedlund, 1990).

Overall, the methodology used has shown a positive association between most of the agro-industrial traits and EY, and the lines BR500R, BR505R, CMSXS633R, CMSXS634R, CMSXS642R, CMSXS643R, and CMSXS644R are most promising for breeding purposes.

\section{Conflicts of interest}

The authors declare no conflict of interest.

\section{ACKNOWLEDGMENTS}

The authors are grateful to Embrapa Milho e Sorgo for the partnership, Fundação de Amparo à Pesquisa do Estado de Minas Gerais (FAPEMIG), Conselho Nacional de Desenvolvimento Científico e Tecnológico (CNPq), and Coordenação de Aperfeiçoamento de Pessoal de Nível Superior (CAPES) for granting the scholarship and financial support in conducting the project.

\section{REFERENCES}

Andersson Y and Hedlund B (1990). Extruded wheat flour: correlation between processing and product quality parameters. Food Qual. Prefer. 2: 201-216. http://dx.doi.org/10.1016/0950-3293(90)90012-J

Audilakshmi S, Mall AK, Swamalatha M and Seetharama N (2010). Inheritance of sugar concentration in stalk (brix), sucrose content, stalk and juice yield in sorghum. Biomass Bioenergy 34: 813-820. http://dx.doi.org/10.1016/j. biombioe.2010.01.025

Azevedo JAG, Pereira JC, Queiroz AC, Carneiro PCS, et al. (2003). Composição químico-bromatológica, fracionamento de carboidratos e cinética da degradação in vitro da fibra de três variedades de cana-de-açúcar (Saccharum spp.). Rev. Bras. Zootec. 32: 1443-1453. http://dx.doi.org/10.1590/S1516-35982003000600019

Bertini CHCM, Almeida WS, Silva APM, Lima e Silva JW, et al. (2010). Análise multivariada e índice de seleção na identificação de genótipos superiores de feijão-caupi. Acta Sci. Agron. 32: 613-619. http://dx.doi.org/10.4025/ actasciagron.v32i4.4631

Consecana (2006). Conselho dos produtores de cana-de-açúcar, açúcar e álcool do estado de São Paulo. Manual de instruções. 5th edn. Piracicaba.

Costa MM, Mauro AO, Unêda-Trevisoli SH, Arriel NHC, et al. (2004). Ganho genético por diferentes critérios de seleção em populações segregantes de soja. Pesqui. Agropecu. Bras. 39: 1095-1102. http://dx.doi.org/10.1590/S0100$\underline{204 X 2004001100007}$

de Figueiredo UJ, Nunes JA, da C Parrella RA, Souza ED, et al. (2015). Adaptability and stability of genotypes of sweet sorghum by GGEBiplot and Toler methods. Genet. Mol. Res. 14: 11211-11221. http://dx.doi.org/10.4238/2015. September.22.15

Gonçalves GM, Viana AP, Neto FVB, Pereira MG, et al. (2007). Seleção e herdabilidade na predição de ganhos genéticos em maracujá-amarelo. Pesqui. Agropecu. Bras. 42: 193-198. http://dx.doi.org/10.1590/S0100-204X2007000200007

Gutjahr S, Clément-Vidal A, Soutiras A, Sonderegger N, et al. (2013). Grain, sugar and biomass accumulation in photoperiod-sensitive sorghum. II. Biochemical processes at internode level and interaction with phenology. Funct. Plant Biol. 40: 355-368. http://dx.doi.org/10.1071/FP12177

Hazel LN (1943). The genetic basis for constructing selection indexes. Genetics 28: 476-490.

Kim M and Day DF (2011). Composition of sugar cane, energy cane, and sweet sorghum suitable for ethanol production at Louisiana sugar mills. J. Ind. Microbiol. Biotechnol. 38: 803-807. http://dx.doi.org/10.1007/s10295-010-0812-8

Lombardi GM, Nunes JA, Parrella RA, Teixeira DH, et al. (2015). Path analysis of agro-industrial traits in sweet sorghum. Genet. Mol. Res. 14: 16392-16402. http://dx.doi.org/10.4238/2015.December.9.8

Mendes FF, Ramalho MAP, Abreu AFB and Silva CA (2009). Index to select the best segregating populations of common beans. Annu. Rep. Bean Improv. Coop. 52: 14-15.

Genetics and Molecular Research 16 (1): gmr16019318 
Mulamba NN and Mock JJ (1978). Improvement of yield potential of the ETO blanco maize (Zea mays L.) population by breeding for plant traits. Egypt. J. Genet. Cytol. 7: 40-51.

Nunes JAR, Ramalho MAP and Abreu AFB (2005). Graphical method in studies of adaptability and stability of cultivars. Annu. Rep. Bean Improv. Coop. 48: 182-183.

Parrella RAC (2011). Melhoramento genético do sorgo sacarino. Rev. Agr. 2: 8-9.

Paula RC, Pires IE, Borges RCG and Cruz CD (2002). Predição de ganhos genéticos em melhoramento florestal. Pesqui. Agropecu. Bras. 37: 159-165. http://dx.doi.org/10.1590/S0100-204X2002000200007

Pedrozo CA, Benites FRG, Barbosa MHP, Resende MDV, et al. (2009). Eficiência de índices de seleção utilizando a metodologia REML/BLUP no melhoramento da cana-de-açúcar. Sci. Agr. 10: 031-036.

Pfeiffer TW, Bitzer MJ, Toy JJ and Petersen JF (2010). Heterosis in sweet sorghum and selection of a new sweet sorghum hybrid for use in syrup production in Appalachia. Crop Sci. 50: 1788-1794. http://dx.doi.org/10.2135/ cropsci2009.09.0475

Quinby JR (1974). Sorghum improvement and the genetics of growth. Texas A\&M University Press, College Station, TX.

Quinby JR, Hesketh JD and Voigt RL (1973). Influence of temperature and photoperiod on floral initiation and leaf number in sorghum. Crop Sci. 13: 243-246. http://dx.doi.org/10.2135/cropsci1973.0011183X001300020028x

R Core Team (2016). R: A language and environment for statistical computing. R Foundation for Statistical Computing, Vienna, Austria. Available at [https://www.R-project.org/]. Accessed February 20, 2016.

Ramalho MAP, Abreu AFB, Santos JB and Nunes JAR (2012). Aplicações da Genética Quantitativa no Melhoramento de Plantas Autógamas. 1st edn. Universidade Federal de Lavras, Lavras.

Rao SS, Patil JV, Prasad PVV, Reddy DCS, et al. (2013). Sweet sorghum planting effects on stalk yield and sugar quality in semi-arid tropical environment. Agron. J. 105: 1458-1465. http://dx.doi.org/10.2134/agronj2013.0156

Regassa TH and Wortmann CS (2014). Sweet sorghum as a bioenergy crop: Literature review. Biomass Bioenergy 64: 348-355. http://dx.doi.org/10.1016/j.biombioe.2014.03.052

Resende MDV and Duarte JB (2007). Precisão e controle de qualidade em experimentos de avaliação de cultivares. Pesqui. Agropecu. Trop. 37: 182-194.

Rohowsky B, Häbler T, Gladis A, Remmele E, et al. (2013). Feasibility of simultaneous saccharification and juice cofermentation on hydrothermal pretreated sweet sorghum bagasse for ethanol production. Appl. Energy 102: 211-219. http://dx.doi.org/10.1016/j.apenergy.2012.03.039

Santos FS, Júnior ATA, Júnior SPF, Rangel RM, et al. (2007). Predição de ganhos genéticos por índices de seleção na população de milho-pipoca. UNB-2U sob seleção recorrente. Bragantia 66: 389-396. http://dx.doi.org/10.1590/ $\underline{\text { S0006-87052007000300004 }}$

Scott A and Knott M (1974). A cluster analysis method for grouping means in analysis of variance. Biometrics 30: $507-$ 512. http://dx.doi.org/10.2307/2529204

Smith HF (1936). A discriminant function for plant selection. Ann. Hum. Genet. 7: 240-250.

Souza VF, Parrella RAC, Tardin FD, Costa MR, et al. (2013). Adaptability and stability of sweet sorghum cultivars. Crop Breed. Appl. Biotechnol. 13: 144-151. http://dx.doi.org/10.1590/S1984-70332013000200007

Teetor VH, Duclos DV, Wittenberg ET, Young KM, et al. (2011). Effects of planting date on sugar and ethanol yield of sweet sorghum grown in Arizona. Ind. Crops Prod. 34: 1293-1300. http://dx.doi.org/10.1016/j.indcrop.2010.09.010

Teixeira CG, Jardine JG, Nicolella G and Zaroni MH (1999). Influência da época de corte sobre o teor de açúcares de colmos de sorgo sacarino. Pesqui. Agropecu. Bras. 34: 1601-1606. http://dx.doi.org/10.1590/S0100-204X1999000900010

Tomar SS, Sivakumar S and Ganesamurthy K (2012). Genetic variability and heritability studies for different quantitative traits in sweet sorghum [Sorghum bicolor (L.) Moench] genotypes. Electron. J. Plant Breed 3: 806-810.

Williams JS (1962). The evaluation of a selection index. Biometrics 18: 375-393. http://dx.doi.org/10.2307/2527479

Wu X, Staggenborg S, Propheter JL, Rooney WL, et al. (2010). Features of sweet sorghum juice and their performance in ethanol fermentation. Ind. Crops Prod. 31: 164-170. http://dx.doi.org/10.1016/j.inderop.2009.10.006

Yan W and Rajcan I (2002). Biplot analysis of test sites and trait relations of soybean in Ontario. Crop Sci. 42: 11-20. http:// dx.doi.org/10.2135/cropsci2002.0011

Genetics and Molecular Research 16 (1): gmr16019318 